\title{
Spatial variability of denitrification along a nitrate-rich seepage chain of lakes (Ruidera Natural Park, Central Spain)
}

\author{
Miguel Álvarez-Cobelas ${ }^{1, *}$, Elisa Piña-Ochoa ${ }^{1}$, Salvador Sánchez-Carrillo ${ }^{1}$ and Antonio \\ Delgado-Huertas ${ }^{2}$ \\ ${ }^{1}$ CSIC-Museo Nacional de Ciencias Naturales, Serrano 115 dpdo., E- 28006 Madrid, Spain. \\ 2 CSIC-Estación Experimental del Zaidín, Profesor Albareda 1, E-18008 Granada, Spain. \\ * Corresponding author: malvarez@mncn.csic.es
}

Received: 23/01/18

Accepted: 22/10/18

\begin{abstract}
Spatial variability of denitrification along a nitrate-rich seepage chain of lakes (Ruidera Natural Park, Central Spain)

Spatial variations of denitrification activity and the relative importance of controlling factors were determined using the isotope pairing technique in a seepage chain of Mediterranean flowthrough lakes (Ruidera lakes) and within a given lake in the chain (Colgada lake), all receiving extremely high nitrogen inputs. The range of denitrification rates measured (28-155 $\mu \mathrm{mol} \mathrm{N} \mathrm{m}-2$ $\mathrm{h}^{-1}$ ) were comparable with rates measured with isotope pairing in other freshwater systems. While the bulk of total denitrification was mostly based on $\mathrm{NO}_{3}$ - from the overlying water, coupled nitrification-denitrification seemed to be lower in all Ruidera lakes. At the regional scale, i.e. lake district, inter-variability in denitrification $(\mathrm{CV}=37 \%)$ was lower than the intra-variability observed in a single lake $(\mathrm{CV}=54 \%)$. In fact, a preliminary meta-analysis of data from published studies suggested that denitrification rate variabilities did not differ statistically between the environmental and regional scales. Dissolved oxygen concentration, dissolved organic carbon content and nitrate from the overlying water were found to be the most important factors affecting the spatial heterogeneity of denitrification rate in the lake complex. At the single-lake scale, only phosphorus explained the variability of denitrification rates observed along its main axis. Our study emphasizes the significance of hotspots in denitrification processes, but also highlights the need for further studies on spatial denitrification given that fact that conflicting controlling factors have been found at different scales. To spatially measure denitrification is complicated due to the intrinsic difficulties of the incubation process and hotspots, which makes modelling indispensable.
\end{abstract}

Key words: isotope pairing technique, lake district, controlling factors, hotspots, meta-analysis

\section{RESUMEN}

Variabilidad espacial de la desnitrificación en una cadena de lagos rica en nitrato y con alimentación subterránea (Ruidera, Centro de España)

Mediante la técnica del par isotópico, estudiamos las variaciones espaciales de la actividad desnitrificante y la importancia relativa de sus factores de control en una cadena de lagos mediterráneos de tipo fluvial (lagunas de Ruidera) y en un lago concreto dentro de la misma (Laguna Colgada), todos los cuales reciben cargas elevadas de nitrógeno. El rango de las tasas

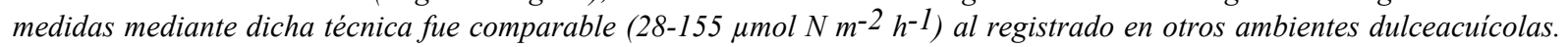
Gran parte de las tasas se debieron al nitrato presente en el agua sobrenadante al sedimento (62-83\%), resultando de menor importancia los procesos acoplados de nitrificación-desnitrificación en todos los lagos estudiados. A escala del conjunto lacustre, la variabilidad del proceso fue inferior $(C V=37 \%)$ a la presente en un único lago $(C V=54 \%)$. En relación con esto, un meta-análisis preliminar de la variabilidad de la desnitrificación en distintos limnoambientes reveló que no había diferencias significativas entre la escala del ecosistema individual y la regional. Las concentraciones de oxigeno disuelto, carbono orgánico disuelto y nitrato en el agua sobrenadante fueron los factores fundamentales que controlaron las tasas de desnitrificación en el conjunto de lagos, mientras que en la laguna Colgada solo el ortofosfato explicó la variabilidad del proceso registrada en su eje principal. Este estudio recalca la importancia de los micrositios más favorables (hotspots) para el proceso de desnitrificación, pero también apoya la necesidad de más estudios sobre el tema porque los factores que lo 
controlan a distintas escalas espaciales difieren entre estudios. Las dificultades intrinsecas a la incubación y a la existencia dichos micrositios para medir espacialmente este proceso mediante cualquier técnica hacen imprescindible la modelización del mismo.

Palabras clave: técnica del par isotópico, territorio de lagos, factores de control, micrositios de proceso más intenso, meta-análisis

\section{INTRODUCTION}

There is little doubt that reactive nitrogen fixed by human activities has risen substantially in the past few decades. Consequently anthropogenic $\mathrm{N}$ is accumulating in aquatic ecosystems and altering many ecological processes (Galloway et al., 2003; Rabalais, 2002; Vitousek et al., 2002).

Denitrification (microbial production of $\mathrm{N}_{2}$ from nitrate and nitrite) is the only process that permanently removes reactive $\mathrm{N}$ from the environment. There are many denitrification studies across different aquatic ecosystems (Piña-Ochoa \& Álvarez-Cobelas, 2006); however, few locations have sufficient measurements to quantify rates, or to understand factors controlling denitrification at the ecosystem scale (Seitzinger $e t$ $a l ., 2006)$. Nowadays, data are available on denitrification activity and its controlling variables across different ecosystems (Cornwell et al., 1999; Mengis et al., 1997; Risgaard-Petersen, 2003; Mulholland et al., 2004; Rissanen et al., 2013) but studies on terrestrial environments far outnumber those on freshwaters (Groffman et al., 2009). Furthermore, denitrification studies regarding spatial heterogeneity are limited and studies using the landscape approach are still scarce. The main reason for this is that field measurements of denitrification are notoriously complicated due to the technical difficulties of measuring $\mathrm{N}_{2}$ production and, even more difficult to resolve, the large spatial variation of process rates involved (Seitzinger et al., 2006). The large spatial variability in production of $\mathrm{N}_{2}$ is influenced by a series of environmental factors, each of which is subject to spatial variability. Therefore, we need to gain a better understanding of variability sources and factors controlling denitrification at the ecosystem level. To date, most studies on the spatial variability of denitrification activity are site-specific and have been performed in streams, alluvial valleys and coastal ecosystems (García-Ruiz et al., 1998; Tuominen et al., 1998; Nielsen et al., 2001; Dong et al., 2000; Orr et al., 2014; Wang et al., 2017). In lakes, however, these studies are still scarce, albeit growing in recent years (Bruesewitz et al., 2012; Rissanen et al., 2011, 2013; Wang et al., 2017).

A combination of factors, which jointly vary, may explain the greatest amount of spatial variation in denitrification. $\mathrm{N}$ loading was shown to influence denitrification rates (García-Ruiz et al., 1998; Nielsen et al., 2001; Wall et al., 2005). Anoxic conditions can constitute a factor controlling the spatial variation in deep areas of the ocean (Tuominen et al., 1998). In an extensive spatial coverage of a coastal ecosystem, Nowicki et al. (1998) attributed spatial differences in denitrification rates to differences in sediment type and organic content. The highest denitrification activity was very often attributable to higher biomasses of benthic fauna (Tuominen et al., 1998; Risgaard-Petersen, 2003; Rysgaard et al., 1995; Nowicki et al., 1998), but it is also dependent upon submerged plant compositions (Caffrey \& Kemp, 1990; Vila-Costa et al., 2016). At the ecosystem scale, geology and hydrology interact to control the residence time of water and thus the processing time of $\mathrm{N}$ within an aquatic ecosystem (Seitzinger et al., 2006) and hence the proportion of $\mathrm{N}$ that can be denitrified. In the Iberian Peninsula, there are still few studies on aquatic denitrification (Piña-Ochoa, 2007; Castellano-Ortigosa et al., 2017; Vila-Costa et al., 2016) while none at all address heterogeneity at different spatial scales.

Here, we explore the spatial intra- and inter-variability in denitrification in a lake district affected by massive $\mathrm{N}$ inputs at two spatial scales: among lakes and within a given lake. We also relate the process variability to the variability of likely controlling factors. Also, a compilation of 

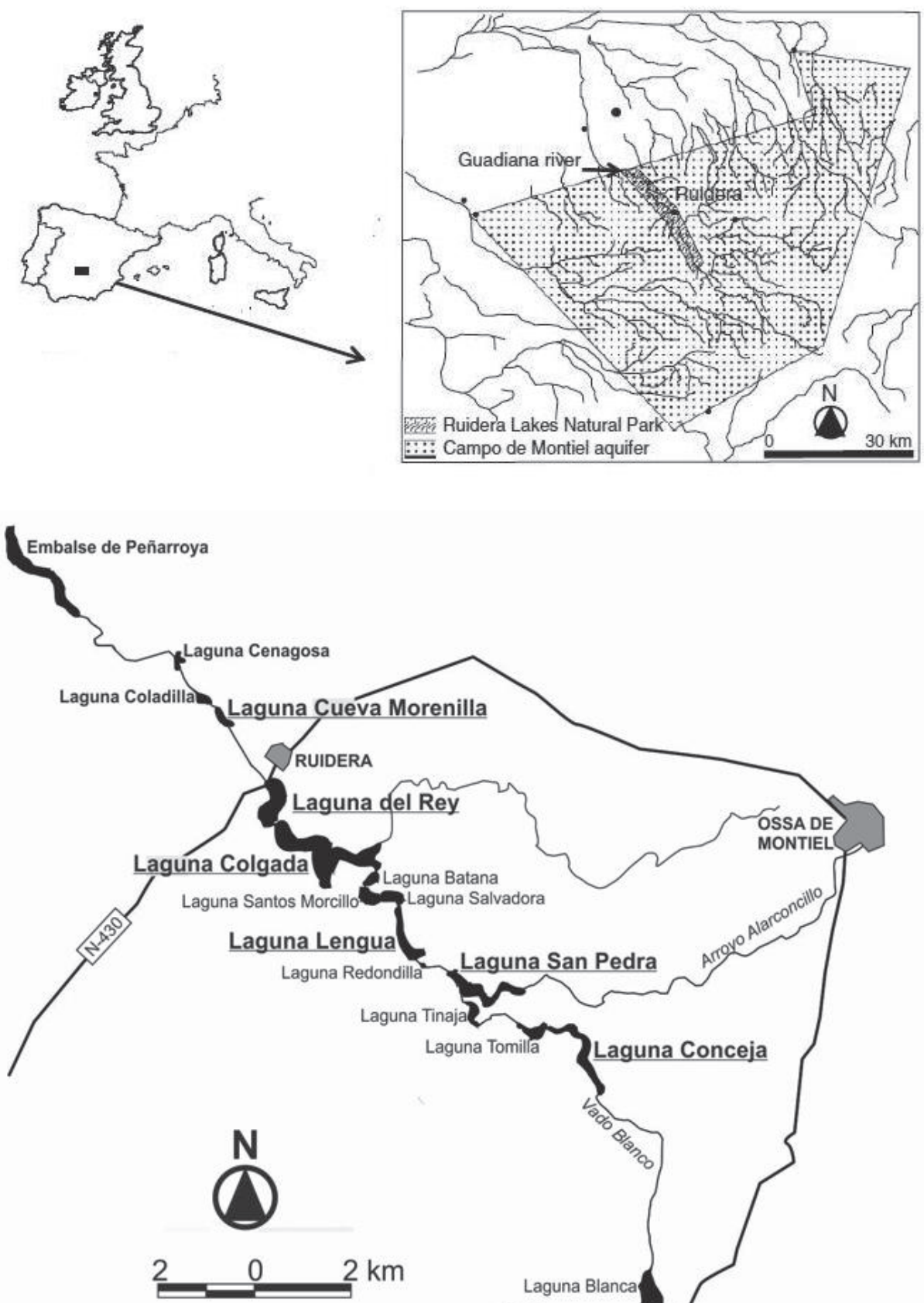

Figure 1. Site location. The Ruidera lake chain where studies in several lakes were undertaken; it runs from the upper ones in the south-eastern area to the lower ones in the north-western area of the catchment. Lugar de estudio. Cadena de lagunas de Ruidera, desde las más altas en la zona SE a las más bajas en la NW. 
studies delving into spatial variability of denitrification rates enable us to perform a preliminary meta-analysis of such variability at the local and the regional scale.

\section{MATERIALS AND METHODS}

\section{Study area}

The Ruidera Lakes Natural Park is located in the Campo de Montiel area of Central Spain $\left(40^{\circ} 55^{\prime}\right.$ $\mathrm{N}, 5^{\circ} 40^{\prime} \mathrm{W}$, Fig. 1). The extension of the geographical area is $4937 \mathrm{~km}^{2}$, whereas that of groundwater catchment is $2575 \mathrm{~km}^{2}$. Surface catchment is smaller, roughly attaining $800 \mathrm{~km}^{2}$. Water is drained to three major watersheds, but that of the Guadiana is by far the largest one. The Ruidera Lakes are comprised by 18 natural basins and a man-made reservoir (Fig. 1). These water bodies are chain-connected, small (0.1-103 ha), shallow or moderately deep (0.5-10.4 m of average depth; Alvarez-Cobelas et al., 2006a). They run SE-NW and are flowthrough, groundwaterand riverine-fed lakes, while Peñarroya reservoir, used for irrigation purposes, stores downstream water drained from both the lakes and the groundwater aquifer.

The order of lakes studied from upstream to downstream is the following: Conceja, San Pedra, Lengua, Colgada, Rey and Cueva Morenilla (Fig. 1). All lakes are warm monomictic and usually stratify from May to October. Most lakes are very similar hypsographically, being convex, except the shallower ones that are more concave. Groundwater inputs feed all lakes, and these may take place through point-source (e.g. subaquatic springs) and/or diffuse flows (Table 1); hence this could be another source of within- and among-lake variability. All lakes have alkalinities ranging between $2.15-4.38 \mathrm{meq} / \mathrm{L}$ and are bicarbonate and calcium-rich environments. Water renewal time of these lakes fluctuates greatly inter-annually (Álvarez-Cobelas et al., 2006b), but during this study period it was much higher than a year (Table 1) when low rainfall made both groundwater level and stream discharge decrease, and hence water volume diminished for most of the lakes under study.

Ruidera lakes are heavily polluted by nitrate inputs through groundwater, whose main origin is agricultural irrigation, with total nitrogen concentrations of 7-17 mg N/L, of which $75-90 \%$ is nitrate. However, $\mathrm{P}$ is the main limiting factor and this results in oligo- to mesotrophic status of lakes due to the small $\mathrm{P}$ concentrations involved (see dissolved N:P ratios in Table 1).

Spatial variability in denitrification in Colgada Lake was surveyed at five equidistant sites along the SE-NW main axis. We would expect some heterogeneity in denitrification activity because this lake receives surface water from the upper lake, two subaquatic and seven surface springs, and through diffuse groundwater input where regional groundwater flows preferably in the SE-NW direction. All Ruidera lakes usually harbour submerged populations of macrophytes (Álvarez-Cobelas et al., 2006a), which might influence processes like denitrification (Caffrey \& Kemp, 1990), but they were largely absent from the main axis during the study because they were too deep to support macrophyte photosynthesis.

\section{Sampling and laboratory incubations}

Six lakes were studied (Conceja, San Pedra, Lengua, Colgada, Rey and Cueva Morenilla) in July 2005. Sampling was undertaken in the central area of each lake, except for Colgada Lake which was surveyed in five different, equidistant sites along its main axis. Seemingly, these sites were environmentally similar, as judged by dissolved oxygen profiles (Álvarez-Cobelas, unpublished data) and visual inspection of cores. Vertical profiles of dissolved oxygen and water temperature were recorded in situ with a Yellow Springs ODO probe at all sites from where sets of cores were retrieved.

The rate of denitrification was determined using the isotope pairing technique (IPT, hereafter; Nielsen, 1992). Sets of eight sediment cores (Plexiglas cylinders, 5.5 inner diameter, $60 \mathrm{~cm}$ height) with 10 to $22 \mathrm{~cm}$ column of sediments were collected at the deepest part of each sampling site (i.e. eight cores per lake in the among-lakes' study and eight cores per site in the within-lake study) and transferred to the laboratory in thermoboxes within $5 \mathrm{~h}$. Care was taken to preserve sediment structure during sampling and 
Table 1. Morphometric and abiotic features of studied lakes in the Ruidera lake chain from the upper SE lake (Conceja) to the lower NW lake (Cueva Morenilla). Dissolved oxygen and nutrient data shown are those recorded at bottom layers of lakes where denitrification cores were retrieved. Datos morfométricos y abióticos de los lagos estudiados en Ruidera, desde el más montano suroriental (Conceja) al más bajo noroccidental (Cueva Morenilla). Los datos de las concentraciones de oxígeno disuelto y nutrientes fueron los registrados en las capas inferiores de los lagos, cuando se tomaron los «cores» para las incubaciones de la desnitrificación.

\begin{tabular}{|c|c|c|c|c|c|c|c|c|c|c|c|c|}
\hline Lake & Elevations & Irface area & Volume & $\begin{array}{c}\text { Maximum } \\
\text { depth }\end{array}$ & $\begin{array}{l}\text { Average } \\
\text { depth }\end{array}$ & $\begin{array}{c}\text { Water } \\
\text { residence } \\
\text { time }\end{array}$ & $\begin{array}{c}\text { Dissolved } \\
\text { oxygen }\end{array}$ & $\mathrm{NO}_{3}$ & DOC & SRP & Dissolved N:P & $\begin{array}{c}\text { Groundwater } \\
\text { inputs }\end{array}$ \\
\hline & (m.a.s.1.) & (Ha) & $\left(\mathrm{Hm}^{3}\right)$ & (m) & (m) & (y) & \multicolumn{4}{|c|}{$\left(\mathrm{mg} \mathrm{O}_{2} / \mathrm{L}\right)(\mathrm{mg} / \mathrm{L})(\mathrm{mg} \mathrm{C} / \mathrm{L})(\mu \mathrm{g} \mathrm{P} / \mathrm{L})$} & (by atoms) & \\
\hline Conceja & 863 & 29 & 2.45 & 14 & 8.37 & 150 & 8.0 & 46.01 & 6.5 & 54 & 91 & Diffuse \\
\hline San Pedra & 836 & 29 & 2.97 & 21 & 10.39 & 125 & 8.3 & 42.12 & 5 & 41 & 109 & Diffuse \\
\hline Lengua & 821 & 20 & 1.36 & 14 & 6.75 & 198 & 9.1 & 46.45 & 2.5 & 0.6 & 8322 & Diffuse \\
\hline Colgada & 799 & 103 & 8.65 & 18 & 8.39 & 108 & 9.2 & 44.53 & 7 & 0.5 & 9520 & Point and diffuse \\
\hline Rey & 799 & 38 & 3.67 & 20 & 9.83 & 186 & 11.8 & 30.75 & 3 & 3 & 1089 & Diffuse \\
\hline Cueva Morenilla & 772 & 7 & 0.39 & 8 & 5.53 & 220 & 9.9 & 31.55 & 3.9 & 2 & 852 & Point and diffuse \\
\hline
\end{tabular}

transport. Bottom water for incubation was pumped from $0.5 \mathrm{~m}$ above the bottom and transported in plastic containers.

In the laboratory each set of sediment cores was opened and immersed in an incubation tank filled with $10 \mathrm{~L}$ bottom water of each site (from either each lake or within-site for the Colgada Lake study), thermostated at in situ temperature. The water column in each core was mixed by small Teflon coated magnets driven by an external magnet (30 r.p.m.), placed $6 \mathrm{~cm}$ above the sediment surface. The $\mathrm{O}_{2}$ concentration was maintained near in situ levels by gentle purging with a $\mathrm{N}_{2}$ /air gas mixture. Prior to incubation experiments, cores were preincubated in the dark at in situ temperature for $2 \mathrm{~h}$. When cores had been thermally stabilized in the tank, incubation was initiated by adding $3.3 \mathrm{ml}$ of a labelled $0.05 \mathrm{M} \mathrm{K} 15 \mathrm{NO}_{3}$ stock solution (98 atom $\%,{ }^{15} \mathrm{NO}_{3}$, Sigma Ltd, UK) into the cores to final concentrations ranging from 480 to 935 $\mu \mathrm{M} \mathrm{NO}_{3}$ and the cores were left to equilibrate the overlying water with pore water. Such a wide range resulted from the wide range of natural $\mathrm{NO}_{3}$ concentration occurring in waters of each set of cores collected at different sites. Such a wide range of resulting $15 \mathrm{~N}$ addition did not affect results because this addition was done in excess regarding the expected isotopic signals after incubations. The enrichment of $15 \mathrm{~N}$ in the water column after isotope addition was $3 \%$.
After $40 \mathrm{~min}$, cores were closed with rubber stoppers having ensured complete mixing of bulk water of the corresponding site at which each core had been retrieved. $\mathrm{NO}_{3}$ concentration in the overlying water was measured before and after $15 \mathrm{NO}_{3}$ addition to estimate $15 \mathrm{~N}$ enrichment. At the initial point of incubation, two samples for time zero were collected as reference cores, and the remaining cores were incubated for $48 \mathrm{~h}$. After incubation end stoppers were removed, $250 \mu \mathrm{L}$ of a $50 \%$ (w/w) $\mathrm{ZnCl}_{2}$ solution were added to each core to stop bacterial activity, resulting in a final concentration of $0.012 \%(\mathrm{w} / \mathrm{w})$ of $\mathrm{ZnCl}_{2}$ in each core. Sediment and water phases were shaken vigorously for several minutes. A sample of resultant sediment slurry was taken with a syringe.

Water samples for nitrate $\left(\mathrm{NO}_{3}\right.$ hereafter), Dissolved Organic Carbon (DOC hereafter), Soluble Reactive Phosphorus (SRP hereafter) and $15 \mathrm{~N}_{2}$ analyses were rapidly taken. Nitrate concentration was too high, therefore the contribution of ammonia as substrate for the nitrification coupling to denitrification process was considered negligible. Dissolved oxygen in each core was measured with a Yellow Springs ODO probe. Slurry samples for $29 \mathrm{~N}_{2}$ and $30 \mathrm{~N}_{2}$ were stored in gas tight containers (Exetainers, Labco, High Wycombe, UK) containing a few drops of $\mathrm{ZnCl}_{2}$ solution $(50 \%, w / w)$. Entrapment of air in the exetainer was carefully avoided. 


\section{Analysis and calculations}

All nutrient analyses $\left(\mathrm{NO}_{3}\right.$, DOC, SRP) of water samples were determined following Standard Methods (APHA, 1998). Water retention time of each lake in July 2005 was estimated knowing maximal lake volumes (Table 1, and see Alvarez-Cobelas et al., 2006), water inputs and changes in lake levels (which enabled to estimate lake volume variation) in the previous year, these latter variables being recorded by the Guadiana Water Authority and the staff of Lagunas de Ruidera Natural Park, respectively.

The concentrations of excess ${ }^{29} \mathrm{~N}_{2}$ and ${ }^{30} \mathrm{~N}_{2}$ in the slurry samples were determined with IPT using a gas chromatograph connected with a Fisons Optima mass spectrometer in the EEZ (CSIC)-stable isotope laboratory. The analytical reproducibility was $\pm 0.1 \%$ for $\delta 15 \mathrm{~N}$, determined from repeated analyses of international nitrogen isotope standards (IAEA-N1 and IAEA-N2).

The $15 \mathrm{~N}_{2}(15 \mathrm{~N} 15 \mathrm{~N}$ and $14 \mathrm{~N} 15 \mathrm{~N})$ of samples was extracted into a helium headspace in the exetainers. After $5 \mathrm{~min}$ of vigorously shaking most $\mathrm{N}_{2}$ was found in the headspace. The gas in the headspace was then injected into a gas chromatograph coupled to the mass spectrometer and the abundance and concentrations of $14 \mathrm{~N} 15 \mathrm{~N}$ and $15 \mathrm{~N} 15 \mathrm{~N}$ were analysed. The gas was purified in a glass column packed with Carbosorb. Additionally, the gas flow was led through a heated copper reduction tube $\left(600^{\circ} \mathrm{C}\right)$.

For further calculations, the interstitial water volume $\left(\mathrm{v}_{\mathrm{iw}}\right)$ of the sediment column of each core was determined as:

$$
\mathrm{v}_{\mathrm{iw}}=((\mathrm{ww}-\mathrm{dw}) / \mathrm{d})
$$

where ww and dw were the wet- and dry weight of each sedimentary sample, respectively, and $\mathrm{d}$ was sediment density. Dry weight was determined after drying sediments at $105^{\circ} \mathrm{C}$ in an oven until constant weight. Sediment density was determined as wet weight of sediment sample/volume of wet sediment sample.

Denitrification rates were estimated from the production of $15 \mathrm{~N}$ isotopes (Nielsen, 1992), using the following formulae:

$$
\begin{aligned}
& \mathrm{D}_{15}=(14 \mathrm{~N} 15 \mathrm{~N})+2 *(15 \mathrm{~N} 15 \mathrm{~N}) \\
& \mathrm{D}_{14}=\left[(14 \mathrm{~N} 15 \mathrm{~N}) /(2 *(15 \mathrm{~N} 15 \mathrm{~N})]^{*} \mathrm{D}_{15}\right. \\
& \mathrm{D}^{\text {tot }}=\mathrm{D}_{14}+\mathrm{D}_{15}
\end{aligned}
$$

where $\mathrm{D}_{15}$ and $\mathrm{D}_{14}$ were the rates of denitrification based on $15 \mathrm{NO}_{3}$ and ${ }^{14} \mathrm{NO}_{3}$, respectively, and $\left({ }^{14} \mathrm{~N} 15 \mathrm{~N}\right)$ and $\left(15 \mathrm{~N}^{15} \mathrm{~N}\right)$ were the rates of production of the two labelled $\mathrm{N}_{2}$ species $\left({ }^{14} \mathrm{~N} 15 \mathrm{~N}\right.$ and ${ }^{15} \mathrm{~N} 15 \mathrm{~N}$, respectively). While $\mathrm{D}_{15}$ expressed denitrification activity of added $15 \mathrm{NO}_{3}, \mathrm{D}_{14}$ expressed in situ total denitrification activity. The denitrification rate obtained was reported in $\mu \mathrm{mol} \mathrm{N} \mathrm{m} \mathrm{N}^{-2} \mathrm{~h}^{-1}$ by multiplying $\mathrm{D}_{14}$ by the total water volume sample ( $=$ volume of water phase + volume of interstitial water phase, $L$ ) and by dividing it by the surface area $\left(\mathrm{m}^{2}\right)$ of the sample and the incubation time (h). The proportion of $\mathrm{D}_{14}$ based on $\mathrm{NO}_{3}$ from the water phase $\left(D_{w}\right)$ was calculated from $D_{15}$ and the $14 \mathrm{~N}: 15 \mathrm{~N}$ ratio of the water column $\mathrm{NO}_{3}$ as follows:

$$
\mathrm{D}_{\mathrm{w}}=\mathrm{D}_{15}\left[{ }^{14} \mathrm{NO}_{3}\right]_{\mathrm{w}} /\left[15 \mathrm{NO}_{3}\right]_{\mathrm{w}}
$$

where $\left[14 \mathrm{NO}_{3}\right.$ - $] \mathrm{w}$ was the concentration of ${ }^{14} \mathrm{NO}_{3}$ and $\left[15 \mathrm{NO}_{3}\right]_{\mathrm{w}}$ was the concentration of $15 \mathrm{NO}_{3}$ in the water column. Finally, in situ denitrification of $\mathrm{NO}_{3}-$ arisen from nitrification $\left(\mathrm{D}_{\mathrm{n}}\right)$ was calculated as:

$$
\mathrm{D}_{\mathrm{n}}=\mathrm{D}_{14}-\mathrm{D}_{\mathrm{w}}
$$

Since denitrification rates among cores are somewhat variable, we decided to undertake simple, non-parametric relationships between them and the likely controlling factors of the denitrification process, using the Spearman correlation approach (Siegel \& Castellan, 1988). Except for water renewal time, which was estimated at the single-lake scale, all remaining environmental factors were those averaged after being measured during core incubations. In order to examine those correlations after partialling out for one or more variables, partial correlations were undertaken with environmental controlling factors of denitrification. All statistical calculations were performed with the STATISTICA7 package. 


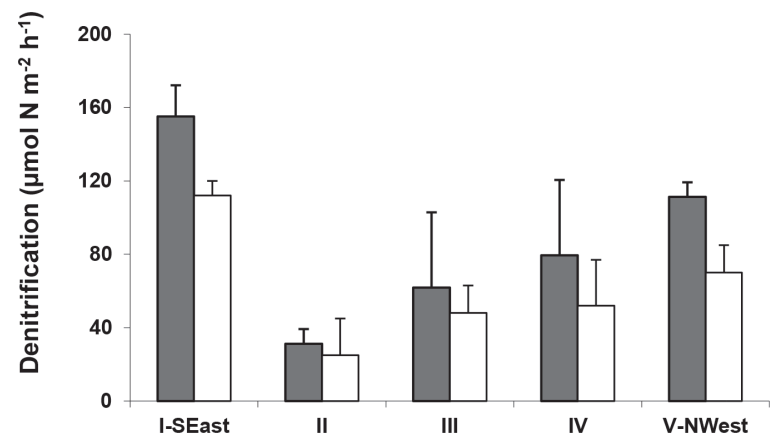

Figure 2. Spatial heterogeneity of denitrification ( $\mu \mathrm{mol} \mathrm{N} \mathrm{m}-2$ $\mathrm{h}^{-1}$, average $\pm 1 \mathrm{SD}$ ) in Colgada Lake on a gradient from SE to NW. Black bars: whole denitrification (water plus sediments); white bars: water denitrification. Heterogeneidad espacial de la desnitrificación (umol $\mathrm{N} \mathrm{m}^{-2} \mathrm{~h}^{-1}$, promedio \pm 1 desviación típica) en el gradiente SE-NW de la laguna Colgada. Barras negras: desnitrificación total (agua + sedimento); barras blancas: desnitrificación en el agua.

\section{RESULTS}

Figure 2 shows the spatial variation of denitrification rates at five different sites in Colgada Lake during July 2005. While rates of total denitrification (Dtot) ranged from $31 \pm 8 \mu \mathrm{mol} \mathrm{N} \mathrm{m}^{-2} \mathrm{~h}^{-1}$ to $155 \pm 17 \mu \mathrm{mol} \mathrm{N} \mathrm{m}{ }^{-2} \mathrm{~h}^{-1}$, both stations being close at the SE end of the lake, denitrification rates in the water column ranged from $25 \pm 20$ $\mu \mathrm{mol} \mathrm{N} \mathrm{m} \mathrm{N}^{-2} \mathrm{~h}^{-1}$ to $112 \pm 8 \mu \mathrm{mol} \mathrm{N} \mathrm{m}{ }^{-2} \mathrm{~h}^{-1}$. There was a statistically significant spatial difference for both types of denitrification (U-test, $p<0.05$ ) across all sampling stations, which were otherwise uncorrelated with each other $(p>0.05)$. Water-phased nitrate denitrification did not correlate with $\mathrm{NO}_{3}$ concentration in the overlying water ( $p>0.05$, t-test).

Total denitrification rates ( $\mathrm{D}^{\text {tot}}$ ) in the Ruidera lake chain ranged from $28 \pm 41$ in Rey Lake to 89 $\pm 21 \mu \mathrm{mol} \mathrm{N} \mathrm{m}-2 \mathrm{~h}^{-1}$ in Conceja Lake (Fig. 3). However, despite the general decrease in $\mathrm{NO}_{3}$ concentration along the lake chain from high to low altitude in the catchment, there was no concomitant pattern in denitrification rates. Nitrate from the overlying water was again the main source of $\mathrm{NO}_{3}$ for denitrification, with $\mathrm{D}_{\mathrm{w}}$ representing $62-83 \%$ of total denitrification rates, and its average rate was $74 \pm 8 \mu \mathrm{mol} \mathrm{N} \mathrm{m}^{-2} \mathrm{~h}^{-1}$.

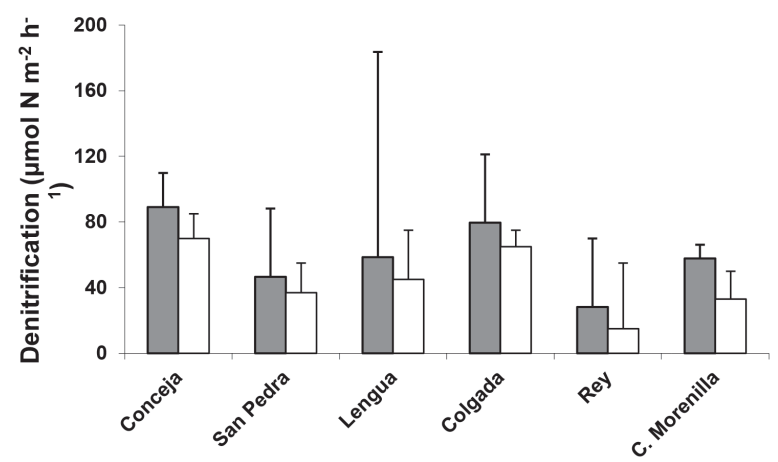

Figure 3. Spatial heterogeneity of denitrification ( $\mu \mathrm{mol} \mathrm{N} \mathrm{m}-2$ $\mathrm{h}^{-1}$, average $\pm 1 \mathrm{SD}$ ) in some lakes of the Ruidera complex, shown from the upper, south-easternmost lake to the lower, north-westernmost lake. Black bars: whole denitrification (water plus sediments); white bars: water denitrification. Heterogeneidad espacial de la desnitrificación ( $\mu \mathrm{mol} \mathrm{N} \mathrm{m}^{-2} \mathrm{~h}^{-1}$, promedio \pm 1 desviación típica) en el gradiente $S E-N W$ de la cadena de lagunas de Ruidera. Barras negras: desnitrificación total (agua + sedimento); barras blancas: desnitrificación en el agua.

Coupled nitrification-denitrification within the sediment $\left(D_{n}\right)$ was negligible in all lakes, thus suggesting that denitrification based on water-phase $\mathrm{NO}_{3}$ played the main role in nitrogen removal in all lakes. Denitrification based on water $\mathrm{NO}_{3}$ showed good correlation $\left(\mathrm{R}^{2}=0.47, p<0.05\right)$ with $\mathrm{NO}_{3}$ concentration in the overlying water.

In the study of spatial heterogeneity of Colgada Lake, denitrification rates were significantly and positively correlated with SRP (Fig. 4; R2 = $0.68, p<0.05)$. The highest SRP concentration occurred at the south-eastern site, which also reached the highest denitrification rates in the lake. $\mathrm{DOC}, \mathrm{NO}_{3}$, dissolved oxygen and water residence time had no significant correlation with denitrification $(p>0.05)$. No partial correlations among controlling variables were found to be statistically significant $(p>0.05)$

Several factors have been shown to influence denitrification activity in the Ruidera Lake chain (Fig. 5). DOC content was significantly and positively correlated $\left(\mathrm{R}^{2}=0.56, p<0.05\right)$ with denitrification rates. The highest organic carbon content occurred in Conceja and Colgada lakes, which had the highest denitrification rates, whereas the lowest denitrification rates corresponded to low organic carbon content of Rey Lake. The denitrification rate showed a negative 
correlation with dissolved oxygen in all lakes $\left(\mathrm{R}^{2}\right.$ $=0.50, p<0.05)$. Also, a positive significant correlation was found between overlying water $\mathrm{NO}_{3}$ and denitrification $\left(\mathrm{R}^{2}=0.59, p<0.05\right)$. The denitrification rate did not show a significant correlation $(p>0.05)$ with any other variable in the correlation analyses; more specifically, water renewal was unrelated with denitrification rates. No partial correlations among controlling variables of denitrification across the lake chain were statistically significant $(p>0.05)$.

The inter-variability in denitrification along the lake chain $(\mathrm{CV}=37 \%)$ was significantly lower (U-test, $p<0.05$ ) than the intra-variability in the single lake $(\mathrm{CV}=54 \%)$.

\section{DISCUSSION}

\section{Denitrification rates}

It has previously been stated that coupled nitrification-denitrification may be the major source of nitrate for denitrification (Seitzinger, 1988; Lohse et al., 1996; Sundbäck and Miles, 2002; Wang et al., 2003; Tuominen et al., 1998), while the water column accounts for $60 \%$ or more of the nitrate for denitrification in other instances (Rysgaard et al., 1995; Nielsen et al., 2001; Dong et al., 2000). Our study indicates the opposite, i.e. uncoupled denitrification $\left(D_{w}\right)$ accounts for a very high fraction of the whole process in Ruidera lakes, a system receiving extremely high nitrogen inputs, whereas coupled nitrification-denitrification did not seem to contribute much to total denitrification. There is considerable variation, however, in the relative importance of both processes, where $\mathrm{NO}_{3}$ concentration in the water overlying sediments can largely explain the wide variability in either the proportion of sediment denitrification supported by coupled nitrification-denitrification or the nitrate content in overlying water. In systems with low nitrate concentrations in bottom water $(<10 \mu \mathrm{M})$, coupled nitrification-denitrification accounts for $90 \%$ or more of the nitrate required to support denitrification. At nitrate concentrations higher than $60 \mu \mathrm{M}$, bottom water becomes the dominant source of nitrate, accounting for $80 \%$ of the overall nitrate required (Seitzinger et al., 2006).

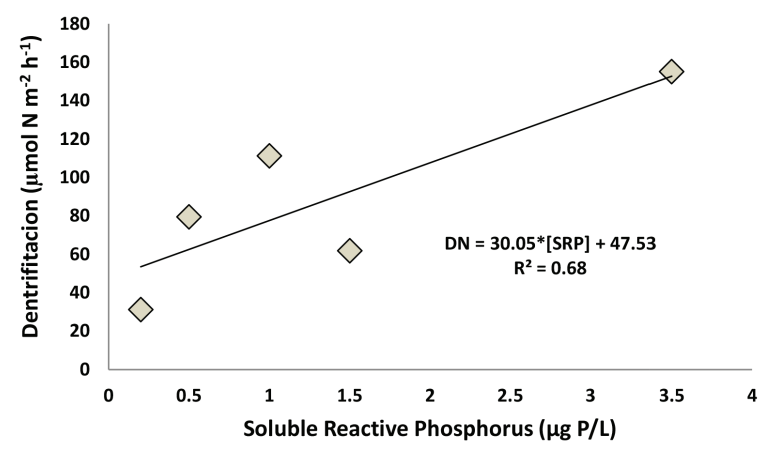

Figure 4. Controlling factor of denitrification in the main axis of Colgada Lake in July 2005, as judged by both a linear regression and the Spearman correlation analysis. All data used in statistical analyses are averages. Factor de control de la desnitrificación en el eje principal de la laguna Colgada en Julio de 2005, analizado mediante regresión lineal y el método de correlación de Spearman. Todos los datos usados en el análisis estadístico son promedios.

As a whole, the range of denitrification rates measured within and among Ruidera lakes (28-155 $\mu \mathrm{mol} \mathrm{N} \mathrm{m}^{-2} \mathrm{~h}^{-1}$ ) were comparable with the rates measured with IPT in other freshwater, estuarine and marine environments (Piña-Ochoa \& Álvarez-Cobelas, 2006), although they were in the upper range. Macrophyte occurrence and composition, previously suggested as mediating factors in this process (Caffrey \& Kemp, 1990; Vila-Costa et al., 2016), can be ruled out as a cause of denitrification variability in Ruidera lakes because they were absent at the main axes of lakes when this study was undertaken.

\section{Controlling factors}

We still lack a comprehensive, quantitative understanding of denitrification rates and controlling factors across ecosystems (Davidson $\&$ Seitzinger, 2006). Furthermore, we suspect that spatial differences in denitrification between lake districts mainly connected by surface waters and those connected by groundwater might be controlled by different sets of variables, also acting differently at the local and the regional scale. Hence, at the lake chain scale, spatial variability in sediment denitrification appeared to be driven by DOC content, $\mathrm{O}_{2}$ concentration, and $\mathrm{NO}_{3}$ content in the overlying water of these seep- 


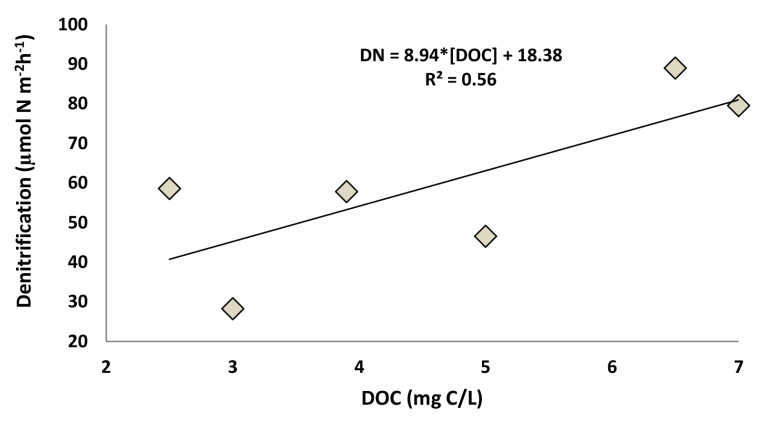

organic carbon was added to lake sediments. On the contrary, Nielsen et al. (2001) could not find such a significant correlation. Denitrification showed a significant negative correlation with dissolved oxygen in all sampled lakes, as also reported by Tuominen et al. (1998). Oxygen-regulated denitrification in lake sediments was thoroughly investigated by Rysgaard et al. (1994).

At Conceja and Colgada lakes, where $\mathrm{NO}_{3}$

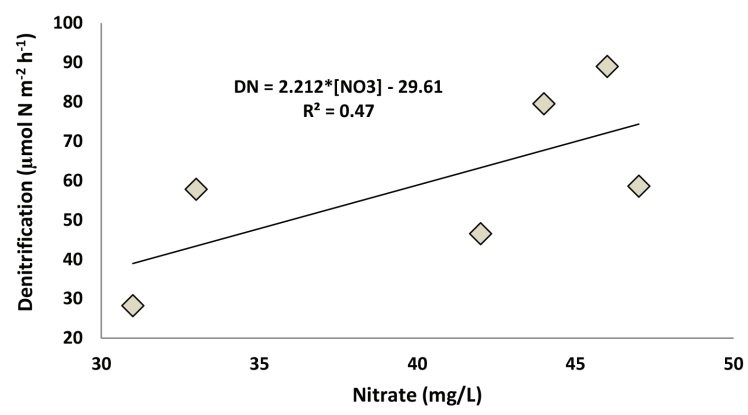
content was the highest among all lakes, denitrification rates were also the highest. Such a straightforward relationship between $\mathrm{NO}_{3}$ and denitrification is consistent with previous reports (Nielsen et al., 2001; Rysgaard et al., 1995; Dong et al., 2000; Wall et al., 2005; Strauss et al., 2006). Water residence time, partly associated with groundwater flux and landscape position, seemingly help to explain divergences in ecosystem response (Webster et al., 2000). However, water residence time did not explain denitrification variability in the lake complex, perhaps because of the lengthy water renewal time observed during our experiments. However, we did not find the same pattern of spatial denitrification observed for nitrate along the lake chain in the single lake.

\section{Heterogeneity at different spatial scales}

Figure 5. Controlling factors of denitrification in the Ruidera lake chain in July 2005, as judged by both a linear regression and the Spearman correlation analyses. All data used in statistical analyses are averages. Factores de control de la desnitrificación en el conjunto de las lagunas estudiadas de Ruidera en Julio de 2005, analizados mediante regresión lineal y el método de correlación de Spearman. Todos los datos usados en el análisis estadístico son promedios.

age lakes. Our results showed that DOC was positively correlated with denitrification rates, where the highest activity occurred in lakes with higher organic carbon content (Conceja and Colgada). This control by DOC was likely the result of DOC compounds' use as electron donors, while $\mathrm{NO}_{3}$ served as oxidant. Similar results were reported by Nowicki et al. (1997) and Mitchell and Baldwin (1999), the latter demonstrating a very strong increase in denitrification rates when

There are very few studies that thoroughly investigate the spatial heterogeneity of denitrification in whole systems or at the ecosystem level. Our study shows that intra-variability in denitrification activity along the main axis of Colgada Lake was high $(\mathrm{CV}=54 \%)$, this variability being higher than inter-variability found along the Ruidera lake chain $(\mathrm{CV}=37 \%)$. Higher $\mathrm{CV}$ of rates as the spatial scale increases was expected since inter-lake variability is normally higher and may be driven by different factors acting at both regional (regional landscape characteristics, climate) and local scale (lake morphometry, hydrology, foodwebs) whereas intra-lake variability is normally attributed to more site-specific factors which can decrease denitrification variability. Some studies (Nowicki et al., 1997; Dong et al., 2000; Tuominen et al., 1998) found significant spatial denitrification differences. However, other studies (Seitzinger et al., 1984; Nielsen et al., 


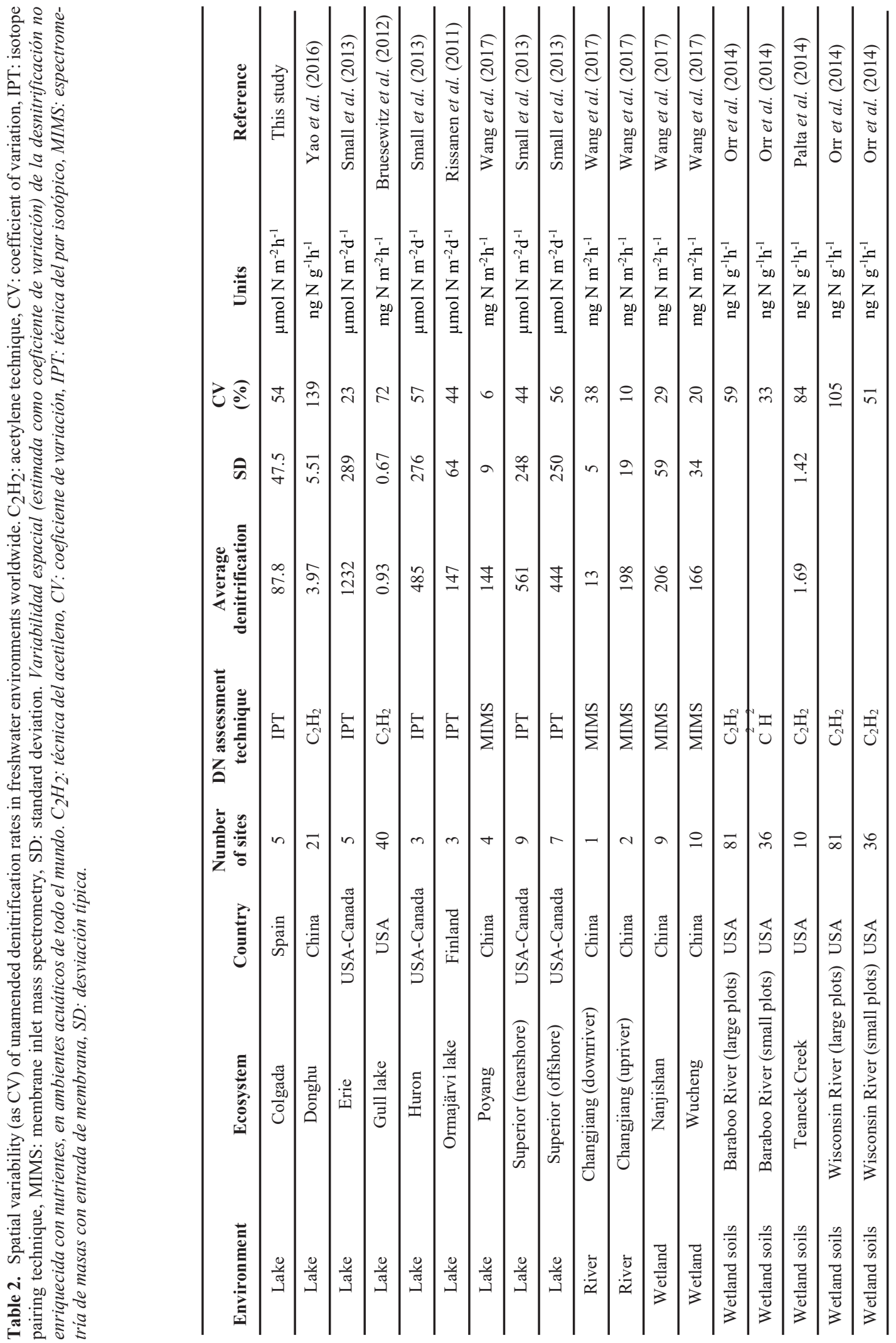


Table 3. Spatial variability (as CV) of unamended denitrification rates in districts of freshwater environments worldwide. Abbreviations as in Table 2. Variabilidad espacial (estimada como coeficiente de variación) de la desnitrificación no enriquecida con nutrientes, a la escala regional de ambientes acuáticos en todo el mundo. Las siglas, como en la Tabla 2.

\begin{tabular}{|c|c|c|c|c|c|c|c|c|}
\hline District & Country & $\begin{array}{l}\text { Number of } \\
\text { ecosystems }\end{array}$ & $\begin{array}{c}\text { DN assessment } \\
\text { technique }\end{array}$ & $\begin{array}{c}\text { Average } \\
\text { denitrification }\end{array}$ & SD & $\begin{array}{l}\mathrm{CV} \\
(\%)\end{array}$ & Units & Reference \\
\hline Fayetteville & USA & 3 & $\mathrm{~N}_{2}$ measurement & 17.7 & 5.5 & 31 & $\mathrm{~g} \mathrm{~N} \mathrm{~m}^{-2} \mathrm{y}^{-1}$ & Grantz et al. (2012) \\
\hline Great Lakes & USA-Canada & 3 & $\mathrm{C}_{2} \mathrm{H}_{2}$ & 0.030 & 0.004 & 15 & $\mu \mathrm{g} \mathrm{N} \mathrm{g}^{-1} \mathrm{~h}^{-1}$ & Small et al. (2016) \\
\hline Rotorua & New Zealand & 10 & $\mathrm{C}_{2} \mathrm{H}_{2}$ & 15.9 & 18.9 & 119 & $\mu \mathrm{g} \mathrm{N} \mathrm{g}^{-1} \mathrm{~h}^{-1}$ & Bruesewitz et al. (2011) \\
\hline Ruidera & Spain & 6 & IPT & 60 & 22 & 37 & $\mu \mathrm{mol} \mathrm{N} \mathrm{m}{ }^{-2} \mathrm{~d}^{-1}$ & This study \\
\hline $\begin{array}{l}\text { Southern } \\
\text { Finland }\end{array}$ & Finland & 4 & IPT & 180 & 85 & 47 & $\mu \mathrm{mol} \mathrm{N} \mathrm{m} \mathrm{N}^{-2} \mathrm{~d}^{-1}$ & Rissanen et al. (2013) \\
\hline Wucheng & China & 6 & MIMS & 145 & 78 & 54 & $\mathrm{mg} \mathrm{N} \mathrm{m}^{-2} \mathrm{~h}^{-1}$ & Wang et al. (2017) \\
\hline $\begin{array}{l}\text { Yunan- } \\
\text { Giuzhou }\end{array}$ & China & 20 & $\mathrm{C}_{2} \mathrm{H}_{2}$ & 1.06 & 0.43 & 41 & $\operatorname{ng~N~g}{ }^{-1} h^{-1}$ & Liu et al. (2015) \\
\hline
\end{tabular}

2001) did not detect significant spatial differences in denitrification, despite strong spatial gradients in benthic nutrient fluxes, organic carbon, salinity and nitrogen content. In fact, different studies suggest different sets of controlling factors at different spatial scales (Rissanen et al., 2011; Palta et al., 2014; this study). This makes spatial denitrification studies very interesting, albeit inconclusive regarding controlling factors. Clearly, more studies are needed.

Comparison of denitrification rates across different freshwater districts and within a single environment resulted in high ranges of variability among (CVs: 15-119 \%) and within (CVs: 6-139 $\%$ ) (Tables 2-3). A naïve idea would be to suggest that larger area ranges would result in higher rate variabilities and thus CVs at the single-lake scale could be lower than CVs at the district scale because higher environmental variability implies higher variability of denitrification rates. However, a preliminary meta-analysis of compiled data in Tables 2-3 does not support such a hypothesis because variabilities of both groups were not statistically different ( $p=0.67$; Mann-Whitney test). Rissanen et al. (2013) report that rate variabilities at both spatial scales are similar, but they can differ when those measurements are undertaken at the continental scale. This highlights the notion of "hotspots" (see below; Groffman et al., 2009), which are sites where micro-environmental conditions enhance denitrification rates from those recorded in neighbour sites.

All in all, our results point to preferential sites of denitrification in a chain of lakes and on the single-lake scale as well. The importance of these hotspots for denitrification has also been suggested by Bruesewitz et al. (2012) for Gull Lake. While the reason for this is obvious (joint conditions of several controlling factors enhancing rates), it is very difficult to gain short-scale knowledge of them prior to $\mathrm{N}$ process incubations, such as those needed for assessing denitrification when using the incubation approach. Therefore, to enhance our knowledge of denitrification at different spatial scales more efforts must be devoted to modelling (Groffman et al., 2009). Thus, irrespective of the difficulties arising from the choice of a given methodology for denitrification assessment (Seitzinger et al., 1993; Groffman et al., 2006), the most problematic issue when dealing with this process appears to be the uncertainty in spatial rates, which is very hard to cope with.

\section{CONCLUDING REMARKS}

Our finding of high spatial intra-variability of denitrification in a single lake may be especially relevant to sampling strategies where spatial and longitudinal studies of denitrification could provide more accurate data of the process. Interand intra-lake variability could be driven by factors that show temporal and spatial variability and that could also be acting at both regional- and local scales. All this would broaden our vision and give a more integrated view of current knowl- 
edge of the denitrification process in lakes. This issue is of great environmental importance in nitrate-polluted lakes like those of the Ruidera complex and others lying in agricultural catchments. However, to accurately tackle the spatial vagaries of the process is highly challenging and hence modelling could be a much cheaper solution to ascertain spatial variability in denitrification rates, at least in freshwaters.

\section{ACKNOWLEDGEMENTS}

We gratefully acknowledge the technical staff of Lagunas de Ruidera Natural Park for assistance and lake level data. We are also grateful to the Guadiana Water Authority for data on water discharge to Ruidera lakes. Field and lab help provided by José María Alonso, Eva López-Delgado and Meritxell Plensa is also acknowledged. Julio Mateo is thanked for constructing the incubators for the isotope pairing technique improving an earlier design by the Swiss EAWAG (Prof. Bernhard Wehrli). This study has been supported by a predoctoral fellowship to E. Piña-Ochoa and the REN-2002-00558 and CGL-2006-2346/HID Projects of the Spanish Ministry of Education and Science. Comments by two helpful referees have greatly improved the final outcome of the study. We are also grateful to Fabiola Barraclough (Interglobe Language Links) for careful checking of English language.

\section{REFERENCES}

APHA, 1998. Standard Methods for the Examination of Water and Wastewater. 20th edition. Washington D.C., USA.

ÁlVAREZ-COBELAS, M., S. CIRUJANO, E. MONTERO, C. ROJO, M. A. RODRIGO, E. PIÑA，J. C. RODRÍGUEZ-MURILLO, O. SORIANO, M. ABOAL, J. P. MARÍN \& R. ARAUJO. 2006a. Ecología acuática y sociedad de las lagunas de Ruidera. CSIC. Madrid. ÁlVAREZ-COBELAS, M., S. CIRUJANO, C. ROJO, M. A. RODRIGO, E. PIÑA, J. C. RODRÍGUEZ-MURILLO \& E. MONTERO. 2006b. Effects of changing rainfall on the limnology of a Mediterranean, flowthroughseepage chain of lakes. International Review of Hydrobiology, 91: 466-482. DOI: 10.1002/ iroh.200510836

BRUESEWITZ, D. A., D. P. HAMILTON \& L. A. SCHIPPER. 2011. Denitrification potential in lake sediment increases across a gradient of catchment agriculture. Ecosystems, 14: 341-352. DOI: 10.1007/s10021-011-9413-2

BRUESEWITZ, D. A., J. L. TANK \& S. K. HAMILTON. 2012. Incorporating spatial variation of nitrification and denitrification rates into whole-lake nitrogen dynamics. Journal of Geophysical Research, 117. DOI: 10.1029/2012JG002006

CAFFREY, J. M. \& W. M. KEMP. 1990. Nitrogen cycling in sediments with submersed macrophytes: microbial transformation and inorganic pools associated with estuarine populations of Potamogeton perfoliatus and Zostera marina. Marine Ecology Progress Series, 66: 147-160.

CASTELLANO-HINOJOSA, A., D. CORREA-GALEOTE, P. CARRILLO, E. J. BEDMAR \& J. M. MEDINA-SÁNCHEZ. 2017. Denitrification and biodiversity of denitrifiers in a high-mountain Mediterranean lake. Frontiers in Microbiology. DOI: 10.3389/fmicb.2017.01911

CORNWELL, J. C., W. M. KEMP \& T. M. KANA. 1999. Denitrification in coastal ecosystems: methods, environmental controls, and ecosystem level controls, a review. Aquatic Ecology, 33: 41-54.

DAVIDSON, E. A. \& S. SEITZINGER. 2006. The enigma of progress in denitrification research. Ecological Applications, 16: 2057-2063.

DONG, L. F., D. C. O. THORTON, D. B. NEDWELL \& G. J. C. UNDERWOOD. 2000. Denitrification in sediments of the River Colne estuary, England. Marine Ecology Progress Series, 203: 109-122.

GALLOWAY, J. N., J. D. ABER, J. W. ERISMAN, S. P. SEITZINGER, R. W. HOWARTH, E. B. COWLING \& B. J. COSBY. 2003. The Nitrogen cascade. Bioscience, 53: 341-356.

GARCÍA-RUIZ, R., S. N. PATTINSON \& B. A. WHITTON. 1998. Denitrification in river sediments: relationship between process rate 
and properties of water and sediment. Freshwater Biology, 39: 467-476.

GRANTZ, E. M., A. KOGO \& J. T. SCOTT. 2012. Partitioning whole-lake denitrification using in situ dinitrogen gas accumulation and intact sediment core experiments. Limnology and Oceanography, 57: 925-935. DOI: 10. 4319/1o.2012.57.4.0925

GROFFMAN, P. M., M. A. ALTABET, J. K. BOHLKE, K. BUTTERBACH-WAHL, M. B. DAVID, M. K. FIRESTONE, A. E. GIBLIN, T. M. KANA, L. P. NIELSEN \& M. A. VOYTEK. 2006. Methods for measuring denitrification: diverse approaches to a difficult problem. Ecological Applications, 16: 2091-2122.

GROFFMAN, P. M., K. BUTTERBACH-WAHL, R. W. FULWEILER, A. J. GOLD, J. L. MORSE, E. K. STANDER, C. TAGUE, C. TONITTO \& P. VIDON. 2009. Challenges to incorporate spatially and temporally explicit phenomena (hot spots and hot moments) in denitrification models. Biogeochemisty, 93: 49-77. DOI: 10.1007/s10533008-9277-5

LIU, W., Z. WANG, Q. ZHANG, X. CHENG, J. LU \& G. LIU. 2015. Sediment denitrification and nitrous oxide production in Chinese plateau lakes with varying watershed land uses. Biogeochemistry, 123: 379-390. DOI: 10.1007/s10533-015-0072-9

LOHSE, L., H. T. KLOOSTERHUIS, W. RAAPHORST \& W. HELDER. 1996. Denitrification rates as measured by the isotope pairing method and by the acetylene inhibition technique in continental shelf sediments of the North Sea. Marine Ecology Progress Series, 132: 169-179.

MENGIS, M., R. GÄCHTER \& B. WEHRLI. 1997. Nitrogen elimination in two deep eutrophic lakes. Limnology and Oceanography, 42: 1530-1543.

MITCHELL, A. M. \& BALDWIN, D. S. 1999. The effects of sediment desiccation on the potential for nitrification, denitrification and methanogenesis in an Australian reservoir. Hydrobiologia, 392: 3-11.

MULHOLLAND, P. J., H. M. VALETT, J.R. WEBSTER, S. A. THOMAS, L. W.
COOPER, S. K. HAMILTON \& B. J. PETERSON. 2004. Stream denitrification and total nitrate uptake rates measured using a field ${ }^{15 \mathrm{~N}}$ tracer addition approach. Limnology and Oceanography, 49: 809-820.

NIELSEN, L. P. 1992. Denitrification in sediment determined from nitrogen isotope pairing. FEMS Microbiology Letters, 86: 357-362.

NIELSEN, K., N. RISGAARD-PETERSEN, B. SOMOD, S. RYSGAARD \& T. BERGO. 2001. Nitrogen and phosphorus retention estimated independently by flux measurements and dynamic modelling in the estuary Randers Fjord, Denmark. Marine Ecology Progress Series, 219: 25-40.

NISHIO, T., I. KOIKE \& A. HATTORI. 1983. Estimation of nitrification and denitrification in coastal and estuarine sediments. Applied and Environmental Microbiology, 45: 444-450.

NOWICKI, B. L., J. A. KELLY, E. REQUINTINA \& D. KEUREN. 1997. Nitrogen losses through sediment denitrification in Boston Harbor and Massachusetts Bay. Estuaries, 20: 626-639.

ORR, C. H., K. I. PREDICK, E. H. STANLEY \& K. L. ROGERS. 2014. Spatial autocorrelation of denitrification in a restored and a natural floodplain. Wetlands, 34: 89-100. DOI: 10.1007/s13157-013-0488-8

PALTA, M. M., J. G. EHRENFELD \& P. M. GROFFMAN. 2014. "Hot spots" and "hot moments" of denitrification in urban brownfield wetlands. Ecosystems, 17: 1121-1137. DOI: $10.1007 / \mathrm{s} 10021-014-9778-0$

PIÑA-OCHOA, E. 2007. Biogeoquímica del nitrógeno en ambientes acuáticos: lagunas de Ruidera. Tesis Doctoral. Universidad Complutense. Madrid. 120 pp.

PIÑA-OCHOA, E. \& M. ÁlVAREZ-COBELAS. 2006. Denitrification in aquatic environments: a cross-system analysis. Biogeochemistry, 81: 111-130.

RABALAIS, N. N. 2002. Nitrogen in aquatic ecosystems. Ambio, 31: 102-112.

RISSANEN, A. J., M. TIIROLA \& A. OJALA. 2011. Spatial and temporal variation in denitrification and in the denitrifier community in a boreal lake. Aquatic Microbial Ecology, 64: 
27-40. DOI: $10.3354 / \mathrm{ame} 01506$

RISSANEN, A. J., M. TIIROLA, S. HIETANEN

\& A. OJALA. 2013. Interlake variation and environmental controls of denitrification across different geographical scales. Aquatic Microbial Ecology, 69: 1-16. DOI: 10.3354/ ame01619

RISGAARD-PETERSEN， N. 2003. Coupled nitrification-denitrification in autotrophic and heterotrophic estuarine sediments: On the influence of benthic microalgae. Limnology and Oceanography, 48: 93-105.

RYSGAARD, S., N. RISGAARD-PETERSEN, N. P. SLOTH, K. JENSEN \& L. P. NIELSEN. 1994. Oxygen regulation of nitrification and denitrification in sediments. Limnology and Oceanography, 39: 1643-1652.

RYSGAARD, S., P. B. CHRISTENSEN \& L. P. NIELSEN. 1995. Seasonal variation in nitrification and denitrification in estuarine sediment colonized by benthic microalgae and bioturbating infauna. Marine Ecology Progress Series, 126: 111-121.

SEITZINGER, S. P. 1988. Denitrification in freshwater and coastal marine ecosystems: ecological and geochemical significance. Limnology and Oceanography, 33: 702-724.

SEITZINGER, S. P., S. W. NIXON \& M. E. Q. PILSON. 1984. Denitrification and nitrous oxide production in a coastal marine ecosystem. Limnology and Oceanography, 29: 73-83.

SEITZINGER, S. P., L. P. NIELSEN, J. CAFFREY \& P. B. CHRISTENSEN. 1993. Denitrification in aquatic sediments: a comparison of three methods. Biogeochemistry, 23: 147-167.

SEITZINGER, S. P., J. A. HARRISON, J. K. BÖHLKE, A. F. BOUWMAN, R. LOWRANCE, B. PETERSON, C. TOBIAS \& G. VAN DRECHT. 2006. Denitrification across landscapes and waterscapes: a synthesis. Ecological Applications, 16: 2064-2090.

SIEGEL, S. \& N. J. CASTELLAN, jr. 1988. Non-parametric Statistics for the behavioral Sciences. 2nd edition. McGraw-Hill. New York.

SMALL, G. E., J. B. COTNER, J. C. FINLAY, R. A. STARK \& R. W. STERNER. 2013.
Nitrogen transformations at the sediment-water interface across redox gradients in the Laurentian Great Lakes. Hydrobiologia, 731: 95-108. DOI: 10.1007/s10750-013-1569-7

SMALL, G. E., J. C. FINLAY, R. M. L. MACKAY, M. J. ROZMARYNOWYCZ, S. BROVOLD, G. S. BULLERJAHN, K. SPOKAS \& R. W. STERNER. 2016. Large differences in potential denitrification and sediment microbial communities across the Laurentian great lakes. Biogeochemistry, 128: 353-368. DOI: 10.1007/s10533-016-0212-x

STRAUSS, E. A., W. B. RICHARDSON, J. C. CAVANAUGH, L. A. BARTSCH, R. B. KREILING \& A. J. STANDORF. 2006. Variability and regulation of denitrification in an Upper Mississippi river backwater. Journal of the North American Benthological Society, 25: 596-606.

SUNDBÄCK K. \& A. MILES. 2002. Role of microphytobenthos and denitrification for nutrient turnover in embayment with floating macroalgal mats: a spring situation. Aquatic Microbial Ecology, 30: 91-101.

SVENSSON, J. M., A. ENRICH-PRAST \& L. LEONARDSON. 2001. Nitrification and denitrification in a eutrophic lake sediment bioturbated by oligochaetes. Aquatic Microbial Ecology, 23: 177-186.

TUOMINEN, L., A. HEINANEN, J. KUPARINEN \& L. P. NIELSEN. 1998. Spatial and temporal variability of denitrification in the sediments of the northern Baltic Proper. Marine Ecology Progress Series, 172: 13-24.

VAN LUIJN, F. P., C. M. BOERS \& L. LIJKLEMA. 1996. Comparison of denitrification rates in lake sediments obtained by the $\mathrm{N}_{2}$ flux method, the $15 \mathrm{~N}$ isotope pairing technique and the mass balance approach. Water Research, 30: 893-900.

VITOUSEK, P. M., S. HÄTTENSCHWILER, L. OLANDER \& S. ALLISON. 2002. Nitrogen and nature. Ambio, 31: 97-101.

VILA-COSTA, M., C. PULIDO, E. CHAPPUIS, A. CALVIÑO, E.O. CASAMAYOR \& E. GACIA. 2016. Macrophyte landscape modulates lake ecosystem-level nitrogen losses through tightly coupled plant-microbe interactions. Limnology and Oceanography, 61: 
78-88. DOI: $10.1002 /$ lno. 10209

WALL, L.G., J. TANK, T. ROYER \& M. BERNOT. 2005. Spatial and temporal variability in sediment denitrification within and agriculturally influenced reservoir. Biogeochemistry, 76: 85-111.

WANG, F., S. K. JUNIPER, S.P. PELEGRÍ \& S. A. MACKO. 2003. Denitrification in sediments of the Laurentian Trough, St. Lawrence Estuary, Quebec, Canada. Estuarine, Coastal and Shelf Science, 57: 515-522.

WANG, H., L. ZHANG, X. YAO, B. SUE \& W. YAN. 2017. Dissolved nitrous oxide and emission relating to denitrification across the Poyang lake aquatic continuum. Journal of
Environmental Sciences, 52: 130-140. DOI: 10.1016/j.jes.2016.03.021

WEBSTER, K. E., P. A. SORANNO, S. B. BAINES, T. K. KRATZ, C. J. BOWSER, P. J. DILLON, P. CAMPBELL, E. J. FEE \& R. E. HECKY. 2000. Structuring features of lake districts: landscape controls on lake chemical responses to drought. Freshwater Biology, 43: 499-515.

YAO, L., X. JIANG, C. CHEN, G. LIU \& W. LIU. 2016. Within-lake variability and environmental controls of sedimentdenitrification and associated $\mathrm{N}_{2} \mathrm{O}$ production in a shallow eutrophic lake. Ecological Engineering, 97: 251-257. DOI: 10.1016/j.ecoleng.2016.10.023

Con el apoyo de:
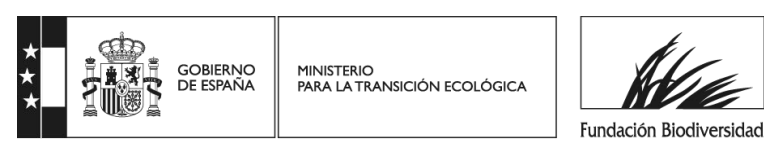